\title{
Effect of different restorative crown design and materials on stress distribution in endodontically treated molars: a finite element analysis study
}

\author{
Jie Lin ${ }^{1,2}$, Zhenxiang $\operatorname{Lin}^{3}$ and Zhiqiang Zheng ${ }^{1 *}$
}

\begin{abstract}
Background: The purposes of this simulation study were to evaluate the stresses in the roots of endodontically treated molars with extensive coronal tissue loss which were restored by endocrowns (all-in-one core and crown) and traditional crowns with post-cores, during masticatory simulation using finite element analysis.

Methods: A mesio-distal cross-section of a lower right first molar was digitized and used to create 2-dimensional models of the teeth and supporting tissue; different crown designs, viz., endocrown with $2 \mathrm{~mm}$ occlusal clearance, endocrown with $4 \mathrm{~mm}$ occlusal clearance and post-core crown; different crown materials, viz., zirconia ( $\mathrm{Zr}$ ) and lithia-disilicate reinforced glass ceramic (LDRGC), and different post and core materials, viz., glass fiber (GF), stainless steel (SS) and metal cast (MC). An axial load of $600 \mathrm{~N}$ was applied to the central fossa of occlusal surface.

Results: The stress distributions were similar between $\mathrm{Zr}$ and LDRGC for periodontal ligament and alveolar bone. The root canal inner wall maximum principal stresses of SS post (70.8 $\mathrm{MPa}$ ) and $\mathrm{MC}$ post $(71.4 \mathrm{MPa})$ were higher than that of GF post (36.0 MPa) and endocrown (2.4 MPa).

Conclusion: The endocrowns reduced stress concentration for the root canal inner wall in comparison with the conventional post-core crown. Molars restored with endocrowns are less prone to root fracture than those with posts.
\end{abstract}

Keywords: Finite element analysis, Endocrown, Post-core crown, Fiber post, Zirconia

\section{Background}

The decision of how to rehabilitate endodontically treated molars (ETM) with extensive loss of coronal structure is a challenge in restorative dentistry. Coronal tooth tissue is often significantly damaged after endodontic treatment and are traditionally restored with metal posts and cores and prosthetic crowns [1-3].

\footnotetext{
* Correspondence: oliverzq@hotmail.com

${ }^{1}$ Fujian Key Laboratory of Oral Diseases, School and Hospital of Stomatology, Fujian Medical University, 246 Yangqiao Zhong Road, Fuzhou, Fujian 350002, People's Republic of China

Full list of author information is available at the end of the article
}

Initially, it was believed that this procedure would provide better reinforcement of the remaining dental structure $[4,5]$. However, it has been observed that the use of intracanal retainers only help in the retention of the prosthetic crown. As a result of removing a dental structure to enable the placement of rigid dental materials devoid of mechanical behaviors similar to those of the tooth, the remaining tooth is weakened [6]. The preparation of a molar for a post in relatively narrow root canals also involves a risk of accidental root perforation and fracture [7].

C C The Author(s). 2020 Open Access This article is licensed under a Creative Commons Attribution 4.0 International License, which permits use, sharing, adaptation, distribution and reproduction in any medium or format, as long as you give appropriate credit to the original author(s) and the source, provide a link to the Creative Commons licence, and indicate if changes were made. The images or other third party material in this article are included in the article's Creative Commons licence, unless indicated otherwise in a credit line to the material. If material is not included in the article's Creative Commons licence and your intended use is not permitted by statutory regulation or exceeds the permitted use, you will need to obtain permission directly from the copyright holder. To view a copy of this licence, visit http://creativecommons.org/licenses/by/4.0/. The Creative Commons Public Domain Dedication waiver (http://creativecommons.org/publicdomain/zero/1.0/) applies to the data made available in this article, unless otherwise stated in a credit line to the data. 
In fact, minimally invasive preparations, with maximal tissue conservation, are now considered 'the gold standard' for restoring ETM [8]. In 1995, the endocrown was described by Pissis who is the forerunner of the endocrown technique, as the 'mono-block porcelain technique' [9]. Currently, due to the advances in adhesive methods and materials, endocrown type of intracoronal restorations were suggested for damaged posterior teeth as an alternative to post and core retained ones [10]. It is a method particularly indicated in cases in which there is excessive loss of hard tissues of the crown, interproximal space is limited, and traditional post-core crown is not possible because of inadequate ceramic thickness [11]. Their advantages include the fact that tooth structures require little preparation, ease of preparation, demand less clinical time when compared with conventional crowns [12,13].

Knowledge of the stress distribution within and around the roots is a key factor for understanding root fracture, which are well-known problems with ETMs. It has been proposed that molars restored with endocrowns are less prone to fracture than those with posts $[14,15]$. Nevertheless, so far there was no clear evidence to prove it. Some studies discussed the effect of preparation designs on the performance of endocrown. Tribst et al. [16] showed in finite element analysis (FEA) study that the stress is more concentrated on the restoration more than the cement line, if the remaining dental tissue is bigger and if the material has high elastic modulus. Dejak et al. [17] compared equivalent stresses in molars restored with endocrowns as well as posts and cores during masticatory simulation using FEA and found the tensile stresses achieved were 4 times higher values than under endocrowns. These tensile stresses occurred in the dentin under the crown shoulder, rather than in the root. Dejak's study described the stress distribution for the crown in detail, while the current study focused on the stress distribution for the root. A similar study by Lin et al. [15] showed that the stress values on the dentin and luting cement for the endocrown restoration were lower than those for the crown. However, these studies made no attempt to compare endocrowns and post-core crowns, relatively little is known about the differences of stress distribution in the roots.

The type of restoration (endocrown or post-core crown, different crown and post materials) will provide rational stress distribution and reduce a risk of fracture in molars? Because of the absence of information about the biomechanical behavior of endocrowns and the expectation that this type of restoration would behave similarly or superiorly to post-core crowns, the present study has aims to evaluate maximum principal stress (MPS) in the roots of ETMs with extensive coronal loss, restored by endocrowns and post-core crowns, during masticatory simulation using FEA, and simulate stresses at the first molar made with different crown and post materials.

\section{Methods}

The research protocol was reviewed and approved by the Research Ethics Committee at the School and Hospital of Stomatology, Fujian Medical University (No. 2017-CX-12).

\section{Structures and geometric conditions of the computer aided design (CAD) model}

A periapical film of the lower right first molar was taken by paralleling technique (Heliodent Plus, Sirona Dental Systems, Bernsheim, Germany) to generate a two dimensional (2D) image file (jpg). Microsoft Office PowerPoint 2007 (Microsoft, USA) was used to trace the points on the X-ray film (Fig. 1a), recorded the coordinate values of red points. The coordinate values of these points are imported into a FEA software (ANSYS v. 10; ANSYS Inc., Canonsburg, PA, USA) through ANSYS parametric design language (APDL) to create the 2D model.

There were three different model designs (Fig. 1), viz., endocrown with $2 \mathrm{~mm}$ occlusal clearance, endocrown with $4 \mathrm{~mm}$ occlusal clearance and post-core crown. The restorations used two different crown materials, viz., zirconia $(\mathrm{Zr})$ and lithia-disilicate reinforced glass ceramic (LDRGC), and three different post and core materials, viz., glass fiber (GF), stainless steel (SS) and metal cast (MC). There were ten kinds of combination in this study. Detailed flowchart showing the group distribution has been included in Fig. 2. In the GF posts and SS posts, the cores were made of composite, while in the $\mathrm{MC}$ posts they were made of metal.

\section{Endocrown and post-core crown designs}

The Endocrown-2 mm designs were created with 2.0 occlusal clearance, $7.0 \mathrm{~mm}$ cavity depth, and $5.3 \mathrm{~mm}$ base width. The prepared cavity walls tapered with 6-8 degrees from the cavity base to the cavosurface (Fig. 1b). The Endocrown $-4 \mathrm{~mm}$ designs were created with 4.0 occlusal clearance, $5.0 \mathrm{~mm}$ cavity depth, $5.3 \mathrm{~mm}$ base width and 6-8 degrees cavity walls taper (Fig. 1c). Jacket crown preparations were created with $2.0 \mathrm{~mm}$ occlusal clearance, $0.5-1.5 \mathrm{~mm}$ cervical clearance and shoulder margin, 6-8 degrees tapering angle for first molars, $14.0 \mathrm{~mm}$ post lengths. Rounded shoulder margins and anatomic occlusal reduction were incorporated in model (Fig. 1d).

The surrounding bone was modeled as cortical bone (1.5 mm thickness) and cancellous bone, which were assumed to be isotropic, homogeneous, and linearly elastic. A $0.2 \mathrm{~mm}$ periodontal ligament $[17,18]$ was modeled around the roots. A $0.1 \mathrm{~mm}$ thick cement-imitating layer $[17,18]$ was formed around the root part of the created post and under the crown. A small gap of cement was 


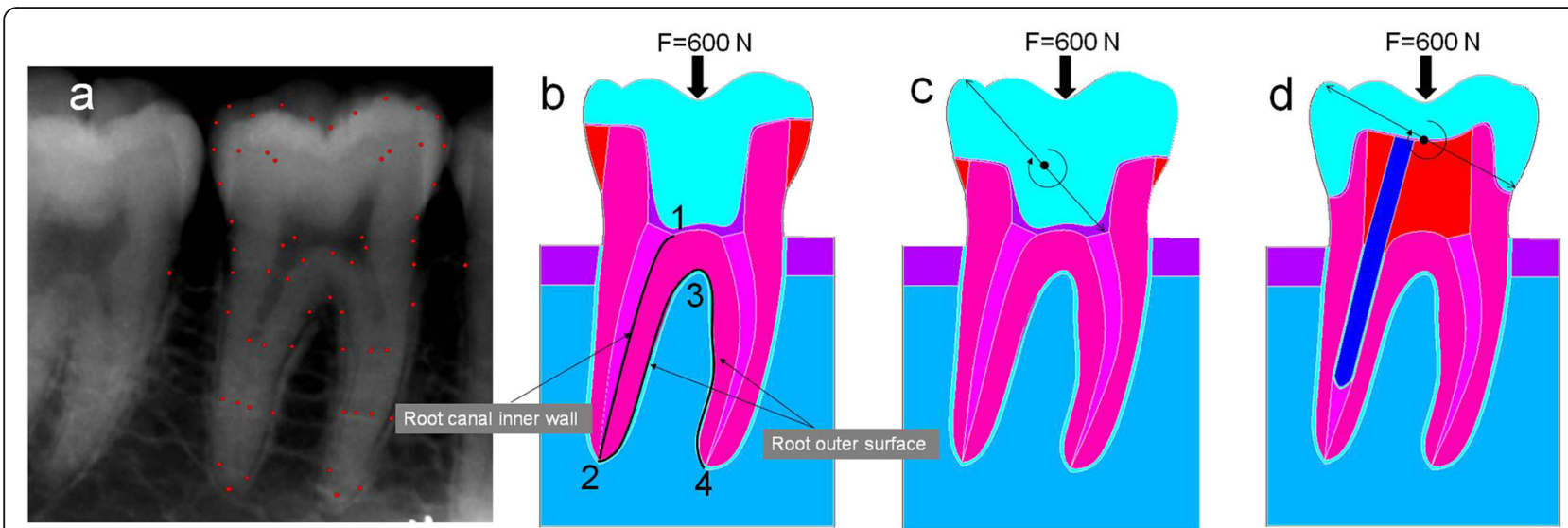

Fig. $12 \mathrm{D}$ models of first mandibular molar tooth with roots and periodontium (bucco -lingual side view). Original contours developed from radiographic image of first mandibular molar tooth. a radiographic image of first mandibular molar tooth, the coordinate values at the red point were extracted. $\mathbf{b}$ endocrown with $2 \mathrm{~mm}$ occlusal clearance, (c) endocrown with $4 \mathrm{~mm}$ occlusal clearance. $\mathbf{d}$ post-core crownThick arrow: simulated $600 \mathrm{~N}$ vertical occlusal load. $1 \rightarrow 2$ : distal root canal inner wall, $2 \rightarrow 3 \rightarrow 4$ : root outer surface. Endocrown geometrically reduced the rotation center of the crown restoration in comparison with the full crown

added to the bottom of the endocrown cavity, which was closer to the clinical situation. Perfect bonding was assumed at all the interfaces, including those between the teeth, the cores, the crowns, the posts and bones.

\section{Material properties, mesh generation and boundary conditions}

The Young's modulus and Poisson's ratios of the materials used are shown in Table 1 [18-26]. Material properties were assumed to be isotropic, homogenous, and linearelastic, except the GF post. The material of GF post was anisotropic (Young's modulus along its long axis was 38.5 $\mathrm{GPa}$, and 12.0 GPa perpendicular to that axis).

For calculation purposes, each tooth model was divided into 2D 4-node structural solid elements (PLAN E42). This element is defined by four nodes having two degrees of freedom at each node: translations in the nodal $\mathrm{x}$ and $\mathrm{y}$ directions. In model with endocrown-2 $\mathrm{mm}, 30,158$ elements joined at 30,318 nodes were used. In model with endocrown-4 mm, 29,663 elements joined at 29,821 nodes were used. In model with post-core crown, 29,847 elements joined at 30,002 nodes were used. The aim of this preliminary FEA was to identify the regions with highest stress concentration within the restoration, especially those along the distal root inner and outer surface. These would be the regions to which shape optimization would be applied. Thus, the mesh around the distal root inner and outer surface was made much finer than those in the other areas, with an average element edge length of $0.05 \mathrm{~mm}$.

Fixed zero-displacement in both the horizontal and vertical directions was defined at the horizontal and vertical cut-planes of the supporting bone. An axial load of $600 \mathrm{~N}$ $[18,27]$ was applied to the central fossa of occlusal surface. MPS values were calculated by FEA along the distal root canal inner wall and the root outer surface (Fig. 1b: $1 \rightarrow 2 \rightarrow 3 \rightarrow 4)$. This FEA study focused on the distal root canal inner wall because the post was set in the distal root canal, from preliminary analysis the distal root canal inner wall was analyzed in greater detail. The stress distribution within the tooth/restoration cross-section was solved with the FEA software (ANSYS).

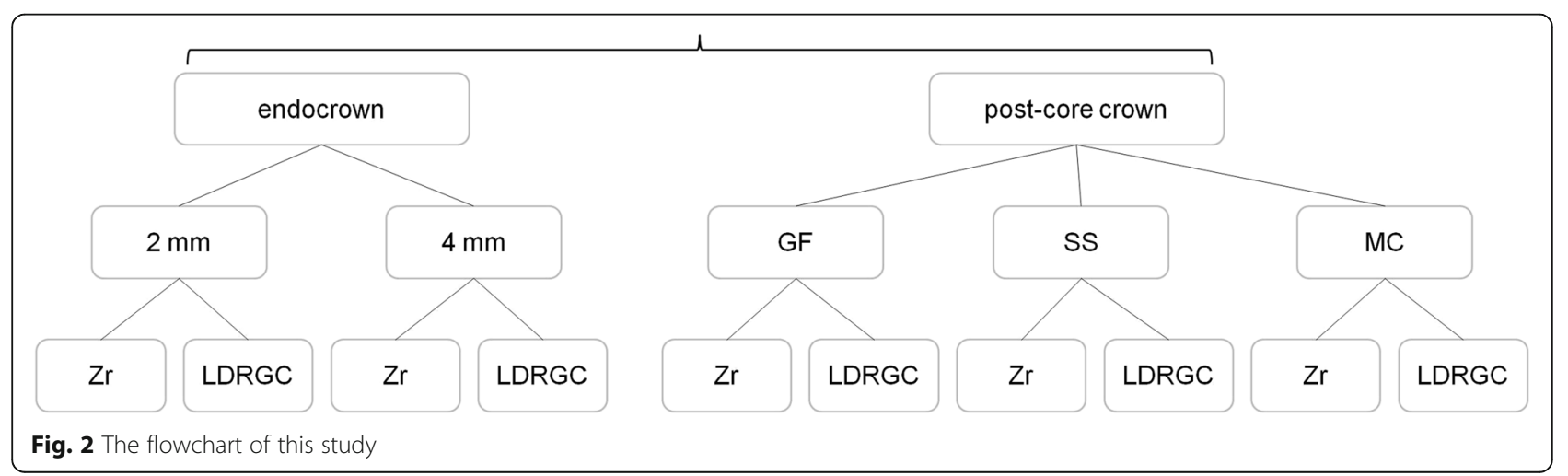


Table 1 Properties of restorative materials and tooth tissue

\begin{tabular}{lll}
\hline & Young's modulus (GPa) & Poisson ratio \\
\hline Enamel [18] & 84.1 & 0.33 \\
Dentin [19] & 18.6 & 0.32 \\
Gutta-percha [20] & 0.14 & 0.45 \\
Periodontium [18] & 0.15 & 0.45 \\
Cortical bone/ Cancellous bone [21] & $13.7 / 1.37$ & 0.3 \\
Luting resin cement [18] & 7.5 & 0.3 \\
LDRGC [22] & 96 & 0.23 \\
Zirconia [18] & 200 & 0.31 \\
Glass fiber post: & $38.5 / 12$ & $0.35 / 0.11$ \\
Fiber_longitudinal/ Fiber_transverse [23] & & 0.33 \\
Metal cast post (Ni-Cr) [24] & 188 & 0.3 \\
Stainless steel post [25] & 210 & 0.3 \\
Composite resin core [26] & 7 & \\
\hline
\end{tabular}

LDRGC: lithia-disilicate reinforced glass ceramic

\section{Results}

MPS analysis for the 2 crown designs, 2 crown materials, 3 post materials tested is presented in Fig. 3. For periodontal ligament and alveolar bone, the stress distributions were similar between $\mathrm{Zr}$ and LDRGC. For the crown, $\mathrm{Zr}$ demonstrated higher and wider range MPS than LDRGC. For the cement layer, crown materials and the thickness influenced the stress distribution, endocrown-2 mm ( $\mathrm{Zr} \quad 31.7 \mathrm{MPa}$, LDRGC $35.9 \mathrm{MPa})$ demonstrated higher MPSes than endocrown- $4 \mathrm{~mm}(\mathrm{Zr}$

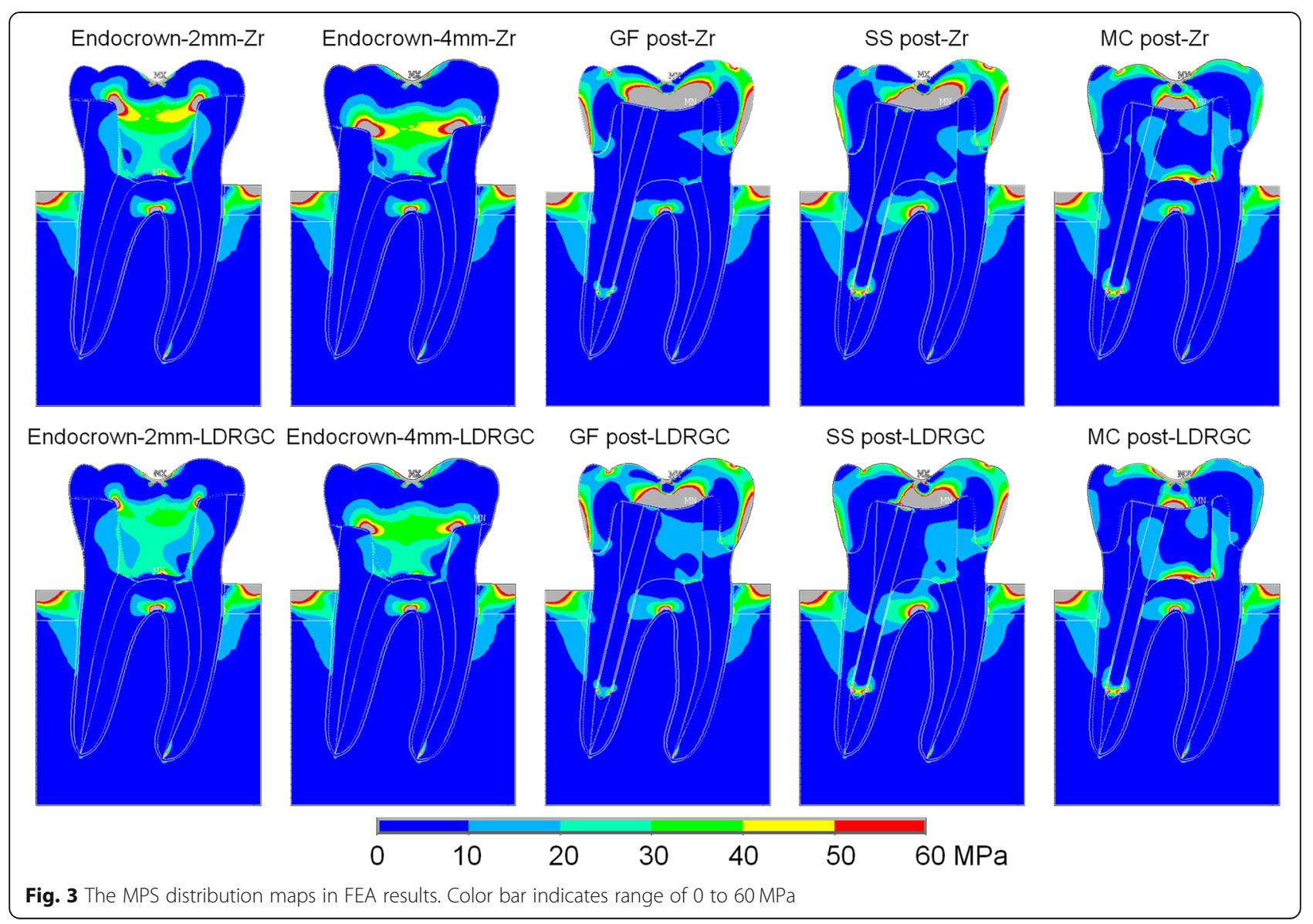


27.2 MPa, LDRGC 31.6 MPa), Zr showed lower MPS than LDRGC.

Figure 4 shows the path plots of the interfacial MPS along the distal root canal inner wall and the root outer surface in endocrown and post-core crown. No difference was found in the $\mathrm{Zr}$ crowns and the LDRGC crowns in the path plots. In the endocrown covered tooth, MPS values of $2.4 \mathrm{MPa}$ were recorded in the distal root canal inner wall. The root canal inner wall stresses of SS post $(70.8 \mathrm{MPa})$ and $\mathrm{MC}$ post $(71.4 \mathrm{MPa})$ were higher than that of $\mathrm{GF}$ post $(36.0 \mathrm{MPa})$ and endocrown $(2.4 \mathrm{MPa})$. The behavior of the endocrown clearly differed from that of the post-core crowns. The endocrown only had one peak (Fig. 4a), nevertheless the post-core crowns had two peaks (Fig. 4b, c and d). The peaks were caused by the root furcation area and the post tip. In the root furcation area, MPS of endocrown achieved a value of $88.7 \mathrm{MPa}$. The endocrown showed higher stresses occurred in the root outer surface than that of post-core crowns.

\section{Discussion}

The numeric FEA modeling is able to reveal the otherwise inaccessible stress distribution within the toothrestoration complex. It has proven to be an important tool in the design process for the understanding of tooth biomechanics and the biomimetic approach [28]. It is undeniable that the $2 \mathrm{D}$ model has its limitations. It can only reflect a simplified plane, and can not fully reflect the three dimensional (3D) structure of teeth, which is not complete in mechanics. The focus of this study was root fracture and stress distribution, so it needed a clear and definite conclusion that the vertical force of the molar with two roots. Although teeth are 3D structures, important mechanical events in endocrown and postcore crown appear within the mesio-distal plane [29]. $2 \mathrm{D}$ abstraction is a highly generalization of the nature of 3D problems. There were many successful applications of $2 \mathrm{D}$ finite element in dentistry in the past five years $[23,30]$. These events support the use of the $2 \mathrm{D}$ plane-
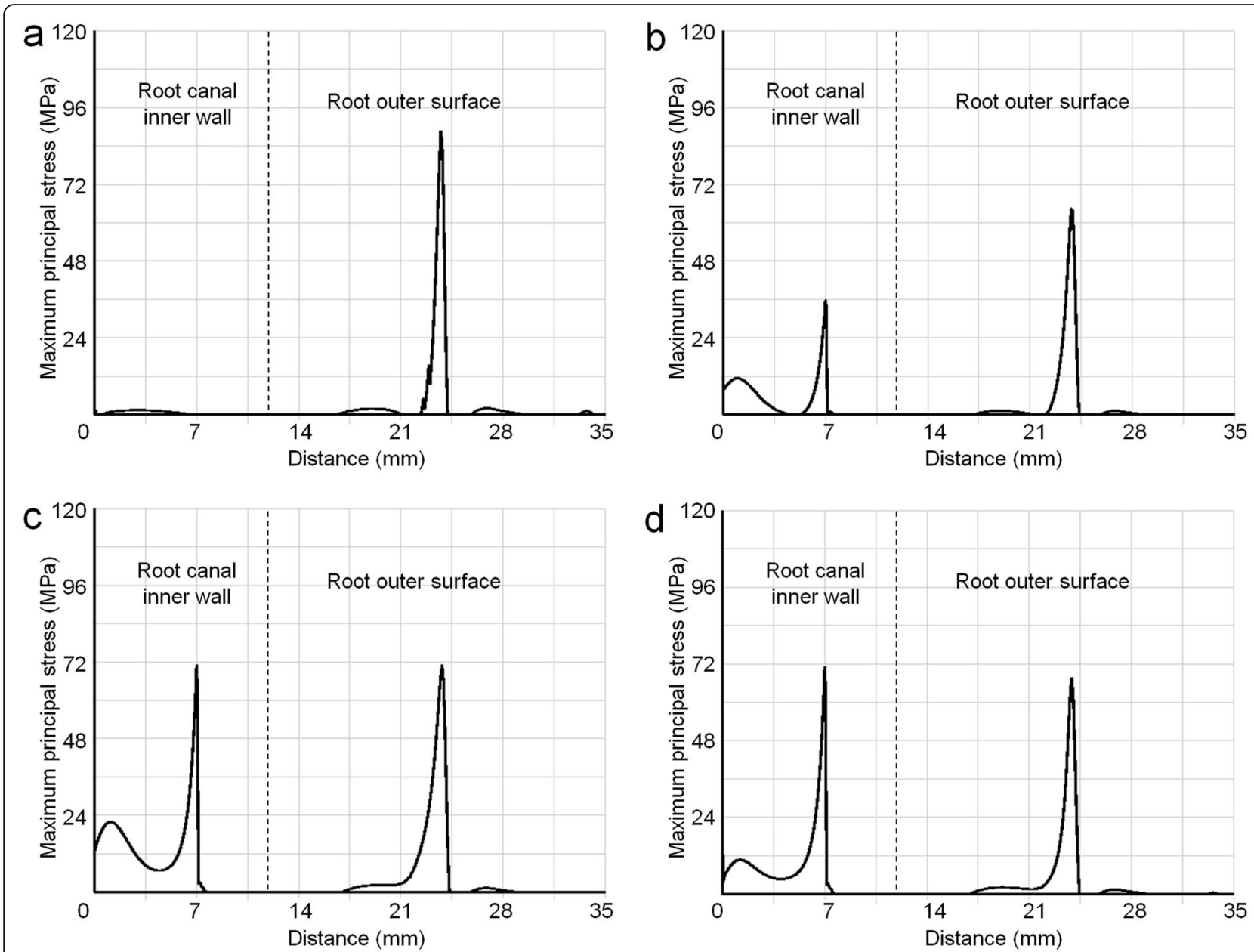

Fig. 4 The path plots of MPS along the distal root canal inner wall (left side, $1 \rightarrow 2$ ) and the root outer surface (right side, $2 \rightarrow 3 \rightarrow 4$ ). a All types of endocrown; $\mathbf{b}$ GF post; $\mathbf{c}$ SS post; $\mathbf{d}$ MC post. The left peaks in $\mathbf{b}, \mathbf{c}$ and $\mathbf{d}$ were caused by the post tip, the right peaks were caused by root furcation area 
strain model for numerical analyses. Volume meshing of $3 \mathrm{D}$ teeth structures is usually restricted to tetrahedral elements. The tetrahedral element has a good ability to model irregular shapes; however, its accuracy is poor for bending and shearing dominated problems. A convergence test is always needed to be conducted to determine the size of elements in finite element modeling. In this $2 \mathrm{D}$ FEA, the mesh was refined continuously until the FEA result did not change greatly. Interface contact analysis was not involved in this study. In contacting surfaces and irregular 3D model usually there are singular points tolerating maximum sharp peak stress. The use of a 2D model is also valuable because of its improved performance in terms of element number and simulation quality.

The stress distribution depends strongly on the functional loads in FEA study. The axial load of $600 \mathrm{~N}$ was to simulate the maximum bite force. Compared with the incisor and canine, the force on the molar is relatively vertical, and many molar related studies use vertical force $[18,27]$. If there is lateral force, it should also be in buccal-lingual section, and this study evaluated mesial-distal section. Even if we change the position and direction of the load, we can still get the result similar to Fig. 4, because the general direction of occlusal force was downward.

Despite great variations in crown material properties, there were only minor differences in the alveolar bone. For a given load configuration, it appears that overall stress distribution within the tooth-bone complex was more influenced by geometry design of restoration (endocrown vs. post-core crown) than by composition (e.g. crown, post and core restorative material type). The endocrown showed a relatively smooth stress distribution in the root and the periodontal support tissue. This is largely due to two reasons: firstly, post-core crown applied extra-coronal retainer, while endocrown used intra-coronal retainer. Endocrown with intracoronal retainer was more conducive to transfer the force to the wall of the pulp chamber and the periodontal tissue, rather than to the root canal wall. Secondly, endocrown geometrically reduced the rotation center of the crown restoration in comparison with the full crown (Fig. 1c and d, ring arrow). This also contributed to transfer the occlusal force to periodontal tissue.

The root canal after instrumentation (root canal or post preparation) is thinner and weaker than the rest of the tooth. Stress concentration at the post tip must therefore be regarded as most harmful. It is precisely in the area of concentrated stresses where differences were found (Fig. 4, the left peaks of SS post and MC post). e.g. stresses in the post tip around SS posts achieved dozens of times higher values than under endocrowns and twice higher values than under GF posts. In this specific zone, low elastic modulus restorative materials showed reduced stresses, which can be explained by the stress redistribution into the more flexible GF post and composite core. Stress concentration of endocrown in the root canal was relatively small, it is good to avoid the weak tip of the post. The molar post-core crown increased the risk of accidental root fracture. The highest MPS in the distal root canal occurred in molar restored with SS and $\mathrm{MC}$ posts. These types of restorations seem to be the least beneficial in molar teeth. Biacchi and Basting [31] found that molars with endocrowns are more fracture resistant than teeth restored with GF posts and cores and ceramic crowns. Taking into consideration the suitable stress distribution of endocrowns, minimal invasive preparation of tooth structures and no roots damage, these restorations can be recommended to use in molars.

Although MPS levels in the root and the periodontal tissue of molars restored with post-core crowns were higher than stress levels in the tooth with the endocrown. The higher stress peaks in the crowns were observed in the materials with higher elastic modulus [18]. $\mathrm{Zr}$ endocrown represented the one condition with a slightly greater amount of stresses concentration in the cavity inner wall when compared to the post-core crowns. Thus, this is regarded as a potential threat, knowing that remaining coronal tooth structure fractured. Lithium disilicate ceramic materials presented acceptable survival and fracture load as long as the material's minimum thickness and the enamel adhesion are respected [32]. In the $4 \mathrm{~mm}$ endocrown, the cement layer is far away from the load point, which is a protection. But increasing the thickness of the prosthesis means reducing the tooth resistance, which needs a balance. On the other hand, experimental strength study by Forberger and Göhring [33], have shown no significant differences between teeth restored with posts and endocrowns in terms of fracture resistance. Under the analytical conditions of this study, the results were largely dependent on the Young's modulus and Poisson ratio of the materials. However in reality there will be other dominating factors such as the bond strength, potential for micro-crack at the interface, fatigue damage potentials both for the hard tissues and the restorative materials. Further experimental studies and clinical trials are needed to validate the results of this FEA study.

\section{Conclusions}

From this study, the following could be concluded:

The endocrowns reduced stress concentration for the root canal inner wall in comparison with the conventional post-core crown. Endocrown exhibited higher stresses occurred at the root outer surface, while postcore crowns showed increased stresses at the root canal inner wall, especially stainless steel and metal cast post. Molars restored with endocrowns are less prone to root fracture than those with posts. The stress distributions in root were similar for different crown materials and different occlusal clearance. 


\section{Abbreviations}

2D: two dimensional; 3D: three dimensional; Zr: zirconia; LDRGC: lithiadisilicate reinforced glass ceramic; GF: glass fiber; SS: stainless steel; MC: metal cast; ETM: endodontically treated molars; FEA: finite element analysis; CAD: computer aided design; N: Newton; MPS: maximum principal stress

\section{Acknowledgements}

The authors wish to thank to Prof. Shinya Akikazu for his advices in performing the experimental analysis.

\section{Authors' contributions}

$J \mathrm{~L}$ and $\mathrm{ZZ}$ conceived and designed the study. $J \mathrm{~L}$ performed the finite element analysis. JL and ZL wrote the paper. ZZ reviewed and edited the manuscript. All authors read and approved the final manuscript.

\section{Funding}

This work was supported by the Fujian province science and technology innovation joint fund project (Grant No. 2017Y9095). The authors declare that the funding bodies had no role in the design of the study, the collection, analysis, and interpretation of data, or in writing the manuscript.

\section{Availability of data and materials}

The complete data and materials described in the research article are freely available from the corresponding author on reasonable request.

\section{Ethics approval and consent to participate}

This study was approved by the Research Ethics Committee of School and Hospital of Stomatology, Fujian Medical University (No. 2017-CX-12). Written informed consent was obtained from all participants in this study.

\section{Consent for publication}

Not applicable.

\section{Competing interests}

The authors have no conflicts of interest relevant to this article.

\section{Author details}

${ }^{1}$ Fujian Key Laboratory of Oral Diseases, School and Hospital of Stomatology, Fujian Medical University, 246 Yangqiao Zhong Road, Fuzhou, Fujian 350002, People's Republic of China. ${ }^{2}$ Department of Crown and Bridge, School of Life Dentistry at Tokyo, The Nippon Dental University, 1-9-20 Fujimi, Chiyoda-ku, Tokyo 102-8159, Japan. ${ }^{3}$ Department of Stomatology, Hospital of Fujian Provincial Authorities, 68 Guping Road, Fuzhou, Fujian 350001, People's Republic of China.

\section{Received: 26 February 2020 Accepted: 10 August 2020} Published online: 18 August 2020

\section{References}

1. Dartora NR, de Conto Ferreira MB, Moris ICM, Brazão EH, Spazin AO, SousaNeto MD, Silva-Sousa YT, Gomes EA. Effect of Intracoronal depth of teeth restored with Endocrowns on fracture resistance: in vitro and 3-dimensional finite element analysis. J Endod. 2018;44(7):1179-85.

2. Schlichting $\mathrm{LH}$, Resende $\mathrm{TH}$, Reis KR, Magne P. Simplified treatment of severe dental erosion with ultrathin CAD/CAM composite occlusal veneers and anterior bilaminar veneers. J Prosthet Dent. 2016;116(4):474-82.

3. Rocca GT, Rizcalla N, Krejci I. Fiber-reinforced resin coating for endocrown preparations: a technical report. Oper Dent. 2013;38(3):242-8.

4. Valdivia ADCM, Rodrigues MP, Bicalho AA, Van Meerbeek B, Sloten JV, Pessoa RSE, Soares CJ. Biomechanical effect of ferrule on incisors restored with a fiberglass post and lithium-disilicate ceramic crown after thermal cycling and fatigue loading. J Adhes Dent. 2018;20(2):133-42.

5. Ferrari M, Sorrentino R, Juloski J, Grandini S, Carrabba M, Discepoli N, Ferrari CE. Post-retained single crowns versus fixed dental prostheses: a 7-year prospective clinical study. J Dent Res. 2017;96(13):1490-7.

6. Soares CJ, Santana FR, Silva NR, Preira JC, Pereira CA. Influence of the endodontic treatment on mechanical properties of root dentin. J Endod. 2007:33(5):603-6.
7. Ferrari M, Vichi A, Grandini S. Efficacy of different adhesive techniques on bonding to root canal walls: an SEM investigation. Dent Mater. 2001;17(5): 422-9.

8. Dietschi D, Duc O, Krejci I, Sadan A. Biomechanical considerations for the restoration of endodontically treated teeth: a systematic review of the literature, part ii (evaluation of fatigue behavior, interfaces, and in vivo studies). Quintessence Int. 2008;39(2):117-29.

9. Pissis P. Fabrication of a metal-free ceramic restoration utilizing the monobloc technique. Pract Periodontics Aesthet Dent. 1995;7(5):83-94.

10. Shin Y, Park S, Park JW, Kim KM, Park YB, Roh BD. Evaluation of the marginal and internal discrepancies of CAD/CAM endocrowns with different cavity depths: an in vitro study. J Prosthet Dent. 2017;117(1):109-15.

11. Gaintantzopoulou MD, El-Damanhoury HM. Effect of preparation depth on the marginal and internal adaptation of computer-aided design/computerassisted manufacture endocrowns. Oper Dent. 2016;41(6):607-16.

12. Gresnigt MM, Özcan M, van den Houten ML, Schipper L, Cune MS. Fracture strength, failure type and Weibull characteristics of lithium disilicate and multiphase resin composite endocrowns under axial and lateral forces. Dent Mater. 2016;32(5):607-14.

13. Rocca GT, Saratti CM, Poncet A, Feilzer AJ, Krejci I. The influence of FRCs reinforcement on marginal adaptation of CAD/CAM composite resin endocrowns after simulated fatigue loading. Odontology. 2016;104(2):220-32.

14. El-Damanhoury HM, Haj-Ali RN, Platt JA. Fracture resistance and microleakage of endocrowns utilizing three CAD-CAM blocks. Oper Dent. 2015;40(2):201-10.

15. Lin CL, Chang YH, Chang CY, Pai CA, Huang SF. Finite element and Weibull analyses to estimate failure risks in the ceramic endocrown and classical crown for endodontically treated maxillary premolar. Eur J Oral Sci. 2010; 118(1):87-93.

16. Tribst JPM, Dal Piva AMO, Madruga CFL, Valera MC, Borges ALS, Bresciani E, de Melo RM. Endocrown restorations: influence of dental remnant and restorative material on stress distribution. Dent Mater. 2018;34(10):1466-73.

17. Dejak B, Młotkowski A. 3D-finite element analysis of molars restored with endocrowns and posts during masticatory simulation. Dent Mater. 2013; 29(12):e309-17.

18. Dal Piva AMO, Tribst JPM, Borges ALS, Souza ROAE, Bottino MA. CAD-FEA modeling and analysis of different full crown monolithic restorations. Dent Mater. 2018;34(9):1342-50.

19. Craig R, Peyton F. Elastic and mechanical properties of human dentin. J Dent Res. 1958;37(4):710-8.

20. Friedman CM, Sandrik JL, Heuer MA, Rapp GW. Composition and mechanical properties of gutta-percha endodontic points. J Dent Res. 1975; 54(5):921-5.

21. Borchers $L$, Reichart $P$. Three-dimensional stress distribution around a dental implant at different stages of interface development. J Dent Res. 1983;62(2): 155-9.

22. Lin J, Shinya A, Gomi H, Shinya A. Finite element analysis to compare stress distribution of connector of lithia-disilicate reinforced glass ceramic and zirconia based fixed partial denture. Odontology. 2012;100(1):96-9.

23. Lin J, Matinlinna JP, Shinya A, Botelho MG, Zheng Z. Effect of fiber post length and abutment height on fracture resistance of endodontically treated premolars prepared for zirconia crowns. Odontology. 2018;106(2): 215-22.

24. Morris HF. The mechanical properties of metal ceramic alloys as cast and after simulated porcelain firing. J Prosthet Dent. 1989;61(2):160-9.

25. Lanza A, Aversa R, Rengo S, Apicella D, Apicella A. 3D FEA of cemented steel, glass and carbon posts in a maxillary incisor. Dent Mater. 2005;21(8): 709-15.

26. Pegoretti A, Fambri L, Zappini G, Bianchetti M. Finite element analysis of a glass fibre reinforced composite endodontic post. Biomaterials. 2002;23(13): 2667-82.

27. Shi L, Fok AS. Structural optimization of the fibre-reinforced composite substructure in a three-unit dental bridge. Dent Mater. 2009;25(6):791-801.

28. Lin J, Zheng Z, Shinya A, Matinlinna JP, Botelho MG, Shinya A. Structural stability of posterior retainer design for resin-bonded prostheses: a 3D finite element study. Odontology. 2015;103(3):333-8.

29. Chuang SF, Yaman P, Herrero A, Dennison JB, Chang CH. Influence of post material and length on endodontically treated incisors: an in vitro and finite element study. J Prosthet Dent. 2010;104(6):379-88.

30. Cerda-Rizo ER, de Paula RM, Vilela A, Braga S, Oliveira L, Garcia-Silva TC, Soares CJ. Bonding interaction and shrinkage stress of low-viscosity bulk fill 
resin composites with high-viscosity bulk fill or conventional resin composites. Oper Dent. 2019;44(6):625-36.

31. Biacchi GR, Basting RT. Comparison of fracture strength of endocrowns and glass fiber post-retained conventional crowns. Oper Dent. 2012;37(2):130-6.

32. Tribst JP, Dal Piva AO, Madruga CF, Valera MC, Bresciani E, Bottino MA, de Melo RM. The impact of restorative material and ceramic thickness on CADICAM endocrowns. J Clin Exp Dent. 2019;11(11):e969-77.

33. Forberger N, Göhring TN. Influence of the type of post andcore on in vitro marginal continuity, fracture resistance, and fracture mode of lithia

disilicate-based all-ceramic crowns. J Prosthet Dent. 2008;100(4):264-73.

\section{Publisher's Note}

Springer Nature remains neutral with regard to jurisdictional claims in published maps and institutional affiliations.

Ready to submit your research? Choose BMC and benefit from:

- fast, convenient online submission

- thorough peer review by experienced researchers in your field

- rapid publication on acceptance

- support for research data, including large and complex data types

- gold Open Access which fosters wider collaboration and increased citations

- maximum visibility for your research: over $100 \mathrm{M}$ website views per year

At $\mathrm{BMC}$, research is always in progress.

Learn more biomedcentral.com/submissions 